\title{
Pengaruh Good Corporate Governance dan Financial Indicators terhadap Financial Distress pada Perusahaan Property dan Real Estate
}

\author{
Retno Mulansari ${ }^{1}$, Wahyu Setiyorini ${ }^{2}$ \\ ${ }^{1}$ Universitas Merdeka Malang, Jalan Terusan Raya Dieng no. 62 - 64, Malang, 65146, Indonesia \\ 2 Universitas Merdeka Malang, Jalan Terusan Raya Dieng no. 62 - 64, Malang, 65146, Indonesia
}

\begin{abstract}
The purpose of this study was to examine and research the effect of Good Corporate Governance and Financial Indicators to Financial Distress.Good Corporate Governance was measured by using the institutional ownership, managerial ownership, director size, and independent board of commissioners. Financial Indicators was measured by using liquidity, profitabilty, and leverage. While the indicator financial distress was using Altman Z"-Score Model. The research method used is hypothesis testing research using multiple linear regression tests. Population of this research are all of property $\mathcal{E}$ real estate sector listed in Indonesia Stock Exchange in the period of 2013-2017. Based on predetermined criteria, the samples obtained were 20 companies. The result of this research showed that institutional ownership, managerial ownership, liquidity, and profitability have significant positive impact on the probability of firm experienced financial distressed and leverage have significant negative impact on the probability of firm experienced financial distressed. While the director size and independent board of commissioners do not affect on the probability of firm experienced financial distressed
\end{abstract}

Keywords: Good Corporate Governance; Financial Indicators; Financial Distress

\begin{abstract}
ABSTRAK
Penelitian ini bertujuan untuk menguji serta meneliti pengaruh good corporate governance dan financial indicators terhadap financial distress. Good Corporate Governance diukur dengan variabel kepemilikan institusional, kepemilikan manajerial, ukuran dewan direksi, dan proporsi komisaris independen. Financial Indicators diukur dengan variabel likuiditas, profitabilitas, dan leverage. Sedangkan indikator untuk financial distress menggunakan model Altman Z"'-Score. Metode penelitian yang digunakan adalah penelitian uji hipotesis dengan menggunakan uji regresi linear berganda. Populasi dalam penelitian ini adalah seluruh perusahaan property \& real estate yang terdaftar di Bursa Efek Indonesia dari tahun 2013-2017. Berdasarkan kriteria yang telah ditetapkan, sampel yang diperoleh sebanyak 20 perusahaan. Hasil penelitian ini menunjukkan bahwa kepemilikan institusional, kepemilikan manajerial, likuiditas dan profitabilitas berpengaruh signifikan positif terhadap kemungkinan perusahaan mengalami kondisi financial distress dan leverage berpengaruh signifikan negatif terhadap kemungkinan perusahaan mengalami kondisi financial distress. Sedangkan ukuran dewan direksi dan proporsi komisaris independen tidak berpengaruh terhadap kemungkinan perusahaan mengalami kondisi financial distress.
\end{abstract}

Kata Kunci: Good Corporate Governanc; Financial Indicators; Financial Distress.

\section{PENDAHULUAN}

Financial distress dapat dialami oleh hampir semua perusahaan, baik perusahaan besar maupun perusahaan kecil yang diakibatkan oleh faktor-faktor penyebab financial distress yang dapat berasal dari dalam (internal) maupun dari luar (external) perusahaan. Salah satu faktor penyebab kesulitan keuangan adalah adanya beberapa kesalahan yang terjadi di dalam perusahaan, pengambilan keputusan yang kurang tepat oleh manajer, dan kelemahan-kelemahan yang saling berhubungan yang dapat menyumbang baik secara langsung maupun tidak langsung terhadap manajemen perusahaan, serta penyebab lain adalah kurangnya upaya pengawasan terhadap kondisi keuangan sehingga penggunaan dana perusahaan kurang sesuai dengan apa yang dibutuhkan.

Hampir di seluruh negara tidak terkecuali diIndonesia, bahwa sektor industri ini memiliki karakteristik sebagai sektor industri yang susah untuk di prediksi dan memiliki risiko yang cukup tinggi. Selain itu sektor property $\mathcal{E}$ real estate paling berdampak secara signifikan akibat perubahan ekonomi, apabila pertumbuhan ekonomi sangat tinggi maka industri ini mengalami booming dan cenderung melakukan suplai yang banyak, namun waktu pertumbuhan ekonomi menurun, sektor ini akan mengalami penurunan yang lumayan drastis, hal inilah yang menyebabkan sektor property $\mathcal{E}$ real estate 
dikatakan sulit diprediksi.

Oleh sebab itu dibutuhkan alat untuk memprediksi kondisi financial distress sebagai indikasi awal terjadinya kebangkrutan dengan tepat. Model yang digunakan untuk memprediksi financial distress adalah dengan menggunakan model Altman (Z-Score).

Seiring dengan berkembangnya zaman, para peneliti mulai mengaitkan hubungan antara corporate governance sebagai salah satu indikator alasan kemungkinan terjadinya kegagalan dalam perusahaan. Menurut Organization for Economic Cooperation and Development (OECD) corporate governance adalah sistem yang dipergunakan untuk mengarahkan dan mengendalikan kegiatan bisnis perusahaan.

Penelitian mengenai kebangkrutan, kegagalan maupun financial distress dapat menggunakan financial indicators untuk memprediksi kondisi perusahaan di masa yang akan mendatang. Dari beberapa indikator yang ada maka untuk menilai suatu keadaan keuangan perusahaan dapat digunakan rasio antara lain rasio likuiditas, profitabilitas dan leverage.

Menurut hasil penelitian terdahulu, terdapat beberapa research gap yang muncul akibat dari perbedaan pengembangan teori dan perumusan logika hipotesis serta perbedaan sampel penelitian. Berdasarkan research gap tersebut maka dapat dilakukan penelitian kembali untuk mengetahui adanya pengaruh antara karakteristik-karakteristik Corporate Governance dan Financial Indicatorss terhadap Financial Distress.

\section{Good Corporate Governance}

Teori keagenan yang dikemukakan oleh Jensen dan Meckling (1976) yang menyatakan bahwa teori keagenan merupakan hubungan kontraktual antara dua pihak yaitu principal dan agent, dimana pemilik perusahaan atau investor menunjuk agen sebagai manajemen yang mengelola perusahaan atas nama pemilik. Pada kenyataanya pihak manajer sering memiliki tujuan lain yang berlawanan dengan tujuan utama untuk memaksimumkan kekayaan pemegang saham tersebut sehingga hal itu dapat menimbulkan konflik kepentingan antara pemegang saham dan manajer perusahaan. Konflik ini disebut sebagai konflik keagenan (agency problem). Selain itu, para manajer yang bertindak sebagai agent diberikan wewenang untuk turun langsung dalam operasi perusahaan sehingga para manajer memiliki informasi yang lebih tentang perusahaan dibandingkan dengan para pemegang saham (principal). Perbedaan informasi yang didapatkan antara principal dan agent dapat menimbulkan asimetri informasi yang dapat merugikan para pemegang saham.

Karena sebab itu, dalam upaya untuk mengurangi terjadinya asimetri informasi dan biaya keagenan yang harus ditanggung oleh perusahaan, diperlukannya penerapan mekanisme corporate governance.Menurut The Indonesian Institute of Corporate Governance (IICG), Good Corporate Governance didefinisikan sebagai : "Struktur, sistem, dan proses yang digunakan oleh organ-organ perusahaan sebagai upaya untuk memberi nilai tamah perusahaan secara berkesinambungan dalam jangka panjang dengan tetap memperhatikan kepentingan stakeholderslainnya berdasarkan peraturan perundangan dan norma yang berlaku." IICG (2009: 3)

Selain itu, menurut Forum for Corporate Governance in Indonesian (2001) mendefinisikan Corporate Governance sebagai seperangkat peraturan yang menetapkan hubungan antara pemegang saham, pengurus pihak kreditur, pemerintah, karyawan serta para pemegang kepentingan intern dan ekstern lainnya sehubungan dengan hak-hak dan kewajiban mereka, atau dengankata lain sistem yang mengarahkan dan mengendalikan perusahaan.

Penerapan corporate governance dalam suatu perusahaan membawa banyak manfaat yang besar dalam membantu pemulihan perekonomian yang sebelumnya dilanda krisis.

\section{Struktur Kepemilikan \\ Kepemilikan Manajerial}

Kepemilikan manajerial adalah kepemilikan saham yang dimiliki oleh pihak manajemen, baik dari kepemilikan dewan komisaris maupun dewan direksi. Dengan adanya kepemilikan manajerial diharapkan mampu mengurangi tingkat agency problem yang timbul dalam perusahaan.

\section{Kepemilikan Institusional}

Kepemilikan institusional merupakan presentase saham yang dimiliki oleh institusi dari keseluruhan saham perusahaan yang beredar. Kepemilikan institusional yang besar (lebih dari 5\%) akan memberikan kemampuan yang lebih baik untuk memonitor. 


\section{Dewan Direksi}

Berdasarkan pasal 1 ayat 5 undang-undang PT direksi merupakan :

“Organ perseroan yang berwenang dan bertanggung jawab penuh atas pengurusan perseroan untuk kepentingan perseroan, sesuai dengan maksud dan tujuan perseroan serta mewakili perseroan, baik di dalam maupun di luar pengadilan sesuai dengan AD perseroan" (Pasal 1 ayat 5 UU PT).

Dewan direksi memiliki wewenang dalam pengambilan keputusan serta menentukan kebijakan di dalam suatu perusahaan secara jangka pendek maupun jangka panjang.

\section{Komisaris Independen}

Komisaris independen adalah anggota dewan komisaris, merupakan pihak diluar perusahaan yang tidak berurusan secara langsung dengan organisasi/perusahaan tersebut, dan tidak mewakili pemegang saham.

\section{Financial Indicators}

Financial indicators dapat dikatakan sebagai indikator kinerja keuangan perusahaan. Kinerja keuangan perusahaan merupakan suatu kondisi keuangan suatu perusahaan maupun pencapaian kinerja oleh perusahaan untuk suatu periode tertentu yang disajikan di dalam laporan keuangan perusahaan (Hanifah, 2013).

\section{Likuiditas}

Likuiditas merupakan suatu rasio keuangan untuk mengukur kemampuan perusahaan dalam memenuhi kewajibannya dalam membayar utang jangka pendek pada saat jatuh tempo.

\section{Profitabilitas}

Rasio profitabilitas merupakan rasio pengukuran untuk mengetahui kemampuan suatu perusahaan dalam menghasilkan laba selama beberapa periode, serta memberikan gambaran terhadap tingkat efektifitas kinerja manajemen dalam pelaksanaan kegiatan operasinya.

\section{Leverage}

Leverage merupakan rasio pengukuran untuk mengetahui tingkat kemampuan perusahaan dalam penggunaan aktiva dan atau dana yang mempunyai beban tetap (hutang atau saham istimewa) dalam rangka merealisasikan tujuan perusaahan untuk memaksimalkan kekayaan pemilik perusahaan.

\section{Financial Distress}

Financial distress merupakan tahap penurunan kondisi suatu perusahaan dalam menghadapi masalah kesulitan keuangan sebelum terjadinya likuidasi ataupun kebangkrutan. Kondisi financial distress dapat menggambarkan kondisi kesehatan suatu perusahaan, dengan diawali dari ketidakmampuan dalam pemenuhan kewajiban-kewajiban yang bersifat jangka pendek termasuk kewajiban likuiditas.

Untuk mengidentifikasi kondisi keuangan perusahaan dapat ditentukan dengan menggunakan model prediksi financial distress yang dihasilkan oleh Altman yaitu Altman (Z-Score). Dalam memprediksi tingkat financial distress pada perusahaan property \& real estate dapat menggunakan varian terakhir yaitu Z"-Score atau Altman Z-Score Modifikasi. Secara sistematis model prediksi Altman Z-Score dapat dirumuskan sebagai berikut:

$$
\text { Z-Score }=6,56 \mathrm{~T}_{1}+3,26 \mathrm{~T}_{2}+6,72 \mathrm{~T}_{3}+1,05 \mathrm{~T}_{4}
$$

Altman menyatakan bahwa jika perusahaan tersebut mempunyai skor $Z>2,60$ maka diklasifikasikan sebagai perusahaan sehat (non financial distress) dan perusahaan yang memiliki skor Z $<1,10$ maka diklasifikasikan sebagai perusahaan yang berpotensial bangkrut. Sedangkan skor antara 1,10 hingga 2,60 diklasifikasikan sebagai perusahaan pada grey area atau daerah kelabu.

Adapun Hipotesis yang akan diuji dalam penelitian ini adalah

$\mathrm{H}_{1}$ : Kepemilikan Institusional berpengaruh signifikan negatif terhadap kondisi Financial Distress

$\mathrm{H}_{2}$ : Kepemilikan manajerial berpengaruh signifikan negatif terhadap kemungkinan terjadinya kondisi financial distress.

$\mathrm{H}_{3}$ : Ukuran Dewan Direksi berpengaruh signifikan secara negatif terhadap kondisi financial distress.

$\mathrm{H}_{4}$ : Proporsi Komisaris Independen berpengaruh signifikan negatif terhadap kondisi financial distress. 
$\mathrm{H}_{5}$ : Likuiditas berpengaruh signifikan negatif terhadap kondisi financial distress.

$\mathrm{H}_{6}$ : Profitabilitas berpengaruh signifikan negatif terhadap kondisi financial distress.

$\mathrm{H}_{7}$ : Leverage berpengaruh secara signifikan positif terhadap kondisi financial distress.

\section{METODE}

\section{Variabel Penelitian}

Pengukuran yang digunakan untuk financial distress dengan menggunakan metode Altman (Z"-Score):

$\mathrm{Z}-\mathrm{Score}=6,56 \mathrm{~T}_{1}+3,26 \mathrm{~T}_{2}+6,72 \mathrm{~T}_{3}+1,05 \mathrm{~T}_{4}$

Keterangan:

$\mathrm{T}_{1}$ : Modal Kerja/ Total Aset

$\mathrm{T}_{2}$ : Laba Ditahan/ Total Aset

$\mathrm{T}_{3}$ : Laba Sebelum Bunga dan Pajak/ Total Aset

$\mathrm{T}_{4}$ : Nilai Buku Ekuitas/ Nilai Buku Total Utang

Untuk variabel kepemilikan institusional diukur dengan membagi saham perusahaan yang dimiliki institusi dengan total saham yang diterbitkan perusahaan. Kepemilikan manajerial merupakan prosentase saham yang dimiliki oleh direksi maupun setiap pihak yang terlibat secara langsung dalam pembuatan keputusan. Jumlah dewan direksi diproksikan dengan menghitung total anggota dewan direksi di dalam perusahaan pada periode $t$, termasuk CEO. Proporsi komisaris independen diukur berdasarkan prosentase komisaris indpenden dalam struktur dewan komisaris perusahaan. Variabel likuiditas dengan menggunakan perhitungan current ratio. Dalam penelitian ini profitabilitas diproksikan dengan Return on Asset (ROA). Dan untuk variabel Leverage dalam penelitian diproksikan dengan total liabilities to total asset.

Pengujian hipotesis pada penelitian ini dengan menggunakan analisis regresi berganda (multiple regression). Model penelitian ini dalam persamaan linear sebagai berikut:

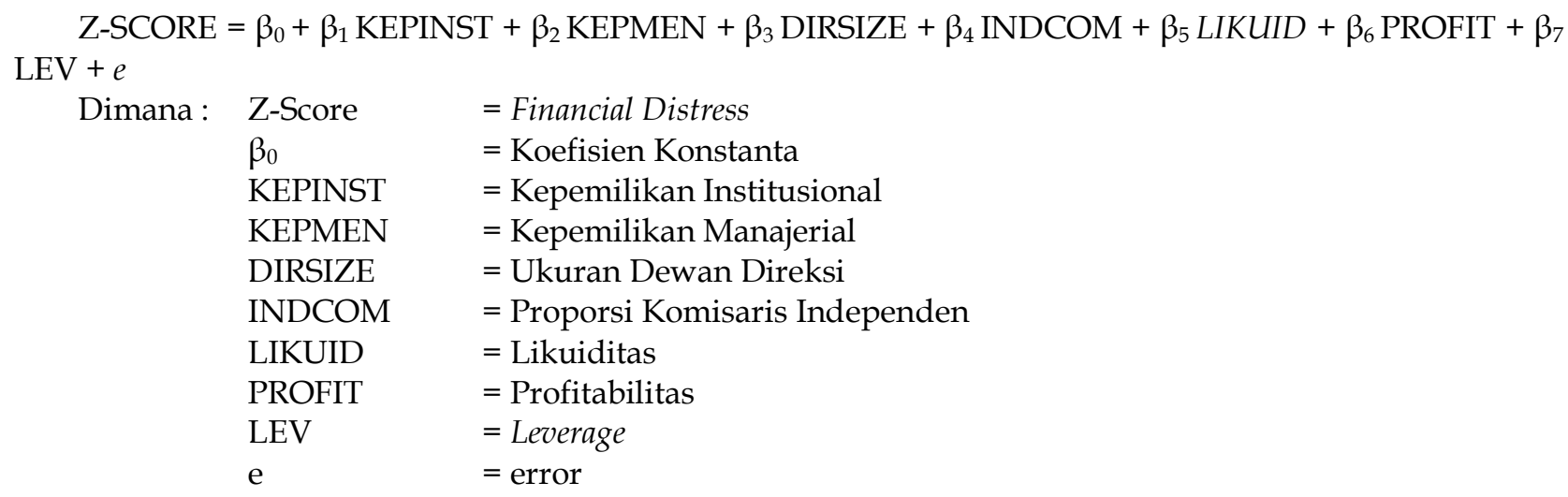

HASIL

Berdasarkan dari pengukuran nilai Z-Score maka diketahui dari 100 sampel sebanyak 5 sampel termasuk dalam kondisi financial distress, 16 sampel termasuk grey area, dan 79 sampel yang termasuk nonfinancial distress.

Tabel 1. Hasil Uji Deskriptif

\begin{tabular}{|l|r|r|r|r|r|}
\hline & $\mathrm{N}$ & Minimum & Maximum & \multicolumn{1}{c|}{ Mean } & \multicolumn{1}{c|}{ Std. Deviation } \\
\hline Z-SCORE & 100 & -.44 & 31.51 & 5.3373 & 4.42725 \\
\hline KEPINST & 100 & 7.21 & 94.39 & 55.8703 & 22.51858 \\
\hline KEPMEN & 100 & .00 & 51.18 & 5.2113 & 12.31449 \\
\hline DIRSIZE & 100 & 2.00 & 12.00 & 4.7800 & 1.98265 \\
\hline INDCOM & 100 & .25 & .67 & .3901 & .08663 \\
\hline LIKUID & 100 & .21 & 10.06 & 2.4515 & 1.83557 \\
\hline PROFIT & 100 & -.08 & .36 & .0570 & .06919 \\
\hline
\end{tabular}




\begin{tabular}{|l|r|r|r|r|r|}
\hline LEV & 100 & .03 & 1.00 & .3701 & .16400 \\
\hline Valid N (listwise) & 100 & & & & \\
\hline
\end{tabular}

Sumber: SPSS (2019)

Dari hasil pengujian statistik deskriptif yang telah dilakukan nilai Z-SCORE diperoleh nilai minimum 0,44 dan nilai maksimum 31,51 dengan rata-rata 5,3373 dan standar deviasi 4,42725. Kepemilikan institusional (KEPINST) diperoleh nilai minimum 7,21 dan nilai maksimum 94,39 dengan rata-rata 55,8703 dan standard deviasi 22,52858. Kepemilikan Manajerial (KEPMEN) diperoleh nilai minimum 0,00 dan nilai maksimum 51,18 dengan nilai rata-rata 5,2113 dan standar deviasi 12,31449. Dewan Direksi (DIRSIZE) dengan nilai minimum 2 dan nilai maksimum 12 dengan nilai rata-rata 4,78 dan standar deviasi 1,98265. Proporsi Komisaris Independen (INDCOM) dengan nilai minimum 0,25 dan nilai maksimum 0,67 dengan nilai rata-rata 0,3901 dan standar deviasi 0,08663. Likuiditas (LIKUID) dengan nilai minimum 0,21 dan nilai maksimum 10,06 dengan nilai rata-rata 2,4515 dan standar deviasi 1,83557. Profitabilitas (PROFIT) dengan nilai minimum $-0,08$ dan nilai maksimum 0,36 dengan rata-rata 0,0570 dan standar deviasi 0,06919 . Leverage (LEV) dengan nilai minimum 0,03 dan nilai maksimum 1,00 dengan nilai rata-rata 0,3701 dan standar deviasi 0,16400.

\section{UJI ASUMSI KLASIK}

UJI NORMALITAS

Tabel 2. Hasil Uji One-Sample Kolmogorov-Smirnov Test

\begin{tabular}{|l|l|r|}
\hline \multicolumn{2}{|c|}{} & $\begin{array}{c}\text { Unstandardized } \\
\text { Residual }\end{array}$ \\
\hline N & Mean & .0000000 \\
\cline { 2 - 3 } & Std. Deviation & 2.01138466 \\
\hline \multirow{2}{*}{ Most Extreme Differences } & Absolute & .133 \\
\cline { 2 - 3 } & Positive & .133 \\
\cline { 2 - 3 } & Negative & -.086 \\
\hline Kolmogorov-Smirnov Z & 1.326 \\
\hline Asymp. Sig. (2-tailed) & .059 \\
\hline $\begin{array}{l}\text { a. Test distribution is Normal. } \\
\text { b. Calculated from data. } \\
\text { Sumber: SPSS (2019) }\end{array}$ & \\
\hline
\end{tabular}

Berdasarkan hasil uji normalitas residual ini, dapat diketahui bahwa nilai signifikansi (Asym.Sig 2tailed) sebesar 0,059 dimana nilai tersebut $>0,05$ maka dapat disimpulkan bahwa nilai residual berdistribusi normal. Oleh sebab itu, data tersebut dapat lanjut ketahap analisis regresi karena syarat dalam uji asumsi klasik data diharuskan berdistribusi normal.

\section{UJI MULTIKOLINEARITAS}

Tabel 3. Hasil Uji Multikolinearitas

\begin{tabular}{|l|l|r|r|}
\hline \multicolumn{2}{|l|}{ Model } & \multicolumn{2}{c|}{ Collinearity Statistics } \\
\cline { 3 - 4 } & & Tolerance & \multicolumn{1}{c|}{ VIF } \\
\hline 1 & (Constant) & & \\
\cline { 2 - 4 } & KEPINST & .514 & 1.946 \\
\cline { 2 - 4 } & KEPMEN & .577 & 1.732 \\
\cline { 2 - 4 } & DIRSIZE & .473 & 2.114 \\
\cline { 2 - 4 } & INDCOM & .660 & 1.515 \\
\cline { 2 - 4 } & LIKUID & .774 & 1.292 \\
\cline { 2 - 4 } & PROFIT & .784 & 1.276 \\
\cline { 2 - 4 } & LEV & .385 & 2.597 \\
\hline
\end{tabular}


Dari hasil pengujian yang telah dilakukan dapat terlihat bahwa hasil outpun, nilai VIF pada kolom Collinearity Statistics untuk variabel $\mathrm{X}_{1}$ (KEPINST) sebesar 1,946, variabel $\mathrm{X}_{2}$ (KEPMEN) sebesar 1,732, variabel $X_{3}$ (DIRSIZE)sebesar 2,114, variabel $X_{4}$ (INDCOM) sebesar 1,515, variabel $X_{5}$ (LIKUID) sebesar 1,292, variabel $X_{6}$ (PROFIT) sebesar 1,276, variabel $X_{7}$ (LEV) sebesar 2,597 semua nilai VIF menunjukkan angka $<10$. Sedangkan nilai Tolerance untuk semua rasio memiliki nilai diatas 0,10 dimana variabel $X_{1}$ (KEPINST) sebesar 0,514, variabel $X_{2}$ (KEPMEN) sebesar 0,577, variabel $X_{3}$ (DIRSIZE) sebesar 0,473, variabel $\mathrm{X}_{4}$ (INDCOM) sebesar 0,660, variabel $\mathrm{X}_{5}$ (LIKUID) sebesar 0,774, variabel $\mathrm{X}_{6}$ (PROFIT) sebesar 0,784, variabel $\mathrm{X}_{7}$ (LEV) sebesar 0,385. Dari hasil nilai VIF dan Tolerance tersebut maka dapat disimpulkan bahwa data tersebut tidak terjadi multikolinearitas antar variabel independen dalam model regresi.

\section{UJI HETEROSKEDASTISITAS}

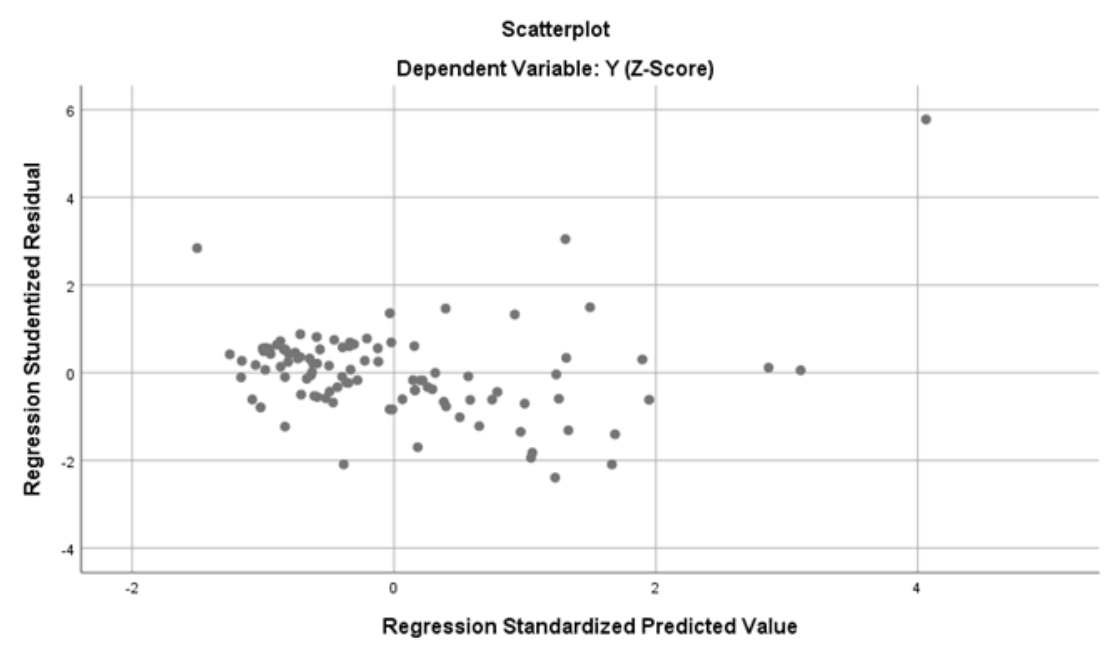

Gambar 1. Scatterplot

Sumber: SPSS (2019)

Dari hasil pengujian heterokedastisitas dengan menggunakan grafik scatterplots dengan jelas menunjukkan bahwa titik-titik grafik tidak membentuk pola yang jelas dan tidak membentuk pola bergelombang, serta penyebaran titik-titik berada di atas maupun di bawah angka 0 pada sumbu Y. Dengan demikin bahwa dapat disimpulkan data dalam pengujian ini tidak terjadi heterokedastisitas dalam model regresi tersebut.

\section{UJI AUTOKORELASI}

Tabel 4. Model Summary

\begin{tabular}{|c|c|c|c|c|c|}
\hline Model & $\mathrm{R}$ & R Square & $\begin{array}{c}\text { Adjusted R } \\
\text { Square }\end{array}$ & $\begin{array}{l}\text { Std. Error of } \\
\text { the Estimate }\end{array}$ & $\begin{array}{l}\text { Durbin- } \\
\text { Watson }\end{array}$ \\
\hline 1 & $.891^{\mathrm{a}}$ & .794 & .778 & 2.08650 & 1.511 \\
\hline \multicolumn{6}{|c|}{$\begin{array}{l}\text { a. Predictors: (Constant), LEV, INDCOM, PROFIT, LIKUID, KEPMEN, } \\
\text { KEPINST, DIRSIZE } \\
\text { b. Dependent Variable: Z-SCORE } \\
\text { Sumber: SPSS (2019) }\end{array}$} \\
\hline
\end{tabular}

Berdasarkan table 4, nilai pada kolom Durbin Watson (DW) sebesar 1,511. Apabila dilihat dari tabel DW untuk 8 variabel yang meliputi 7 variabel independen dan 1 variabel dependen maka $\mathrm{k}=8$ dengan jumlah sampel $\mathrm{n}=100$, untuk level signifikansi $=0,05$ maka diperoleh $\mathrm{du}=1,8498$ sehingga nilai $4-\mathrm{dW}=4-1,511$ $=2,489$. Maka dL $<(4-\mathrm{dW})>\mathrm{dU}$ atau 1,5060<2,489 > 1,8498 menunjukkan bahwa data variabel tidak terjadi autokorelasi. Oleh sebab itu dapat disimpulkan bahwa penelitian ini bebas dari asumsi autokorelasi. 


\section{UJI HIPOTESIS}

Tabel 5. Coefficients

\begin{tabular}{|l|l|r|r|r|}
\hline \multicolumn{2}{|c|}{} & \multicolumn{2}{|c|}{$\begin{array}{c}\text { Unstandardized } \\
\text { Coefficients }\end{array}$} & $\begin{array}{c}\text { Standardized } \\
\text { Coefficients }\end{array}$ \\
\cline { 3 - 5 } \multicolumn{2}{|c|}{ Model } & \multicolumn{1}{|c|}{ B } & Std. Error & \multicolumn{1}{c|}{ Beta } \\
\hline \multirow{4}{*}{1} & (Constant) & -1.252 & 2.044 & .180 \\
\cline { 2 - 5 } & KEPINST & .035 & .013 & .229 \\
\cline { 2 - 5 } & KEPMEN & .082 & .022 & .048 \\
\cline { 2 - 5 } & DIRSIZE & .107 & .154 & .052 \\
\cline { 2 - 5 } & INDCOM & 2.635 & 2.980 & .187 \\
\cline { 2 - 5 } & LIKUID & 1.673 & .130 & -.214 \\
\cline { 2 - 5 } & PROFIT & 11.988 & 3.423 & \\
\cline { 2 - 5 } & LEV & -5.789 & 2.061 & \\
\hline
\end{tabular}

Sumber: SPSS (2019)

Berdasarkan hasil data pada tabel 5 maka dapat dirumuskan dalam persamaan regresi linear berganda sebagai berikut :

Z-SCORE $=-1,252+0,035$ KEPINST $+0,082$ KEPMEN $+0,107$ DIRSIZE $+2,635$ INDCOM+ 1,673 LIKUID+ 11,988 PROFIT -5,789 LEV+e

Dari hasil persamaan regresi linear berganda tersebut maka dapat diketahui bahwa konstanta sebesar $-1,252$. Untuk $\beta_{1}$ sebesar 0,035 yang artinya setiap kenaikan jumlah kepemilikan institusional sebesar $1 \%$ akan diikuti oleh kenaikan Z-Score sebesar 0,035. Untuk $\beta_{2}$ sebesar 0,082 yang artinya setiap kenaikan jumlah kepemilikan manajerial sebesar $1 \%$ akan diikuti oleh kenaikan Z-Score sebesar 0,082 . Untuk $\beta_{3}$ sebesar 0,107 yang artinya setiap kenaikan ukuran dewan direksi sebesar $1 \%$ akan diikuti oleh kenaikan ZScore sebesar 0,107. Untuk $\beta_{4}$ sebesar 2,635 yang artinya setiap kenaikan jumlah proporsi komisaris independen sebesar 1\% akan diikuti oleh kenaikan Z-Score sebesar 2,635. Untuk $\beta_{5}$ sebesar 1,673 yang artinya setiap kenaikan jumlah likuiditas sebesar $1 \%$ akan diikuti oleh kenaikan Z-Score sebesar 1,673. Untuk $\beta_{6}$ sebesar 11,988 yang artinya setiap kenaikan jumlah profitabilitas sebesar $1 \%$ akan diikuti oleh kenaikan Z-Score sebesar 11,988. Untuk $\beta_{7}$ sebesar -5,789 yang artinya setiap kenaikan jumlah leverage sebesar $1 \%$ akan diikuti oleh kenaikan Z-Score sebesar -5,789.

\section{KOEFISIEN DETERMINASI}

Tabel 6. Model Summary

\begin{tabular}{|l|r|r|r|r|}
\hline Model & $\mathrm{R}$ & R Square & $\begin{array}{c}\text { Adjusted R } \\
\text { Square }\end{array}$ & $\begin{array}{c}\text { Std. Error of } \\
\text { the Estimate }\end{array}$ \\
\hline 1 & $.891^{\mathrm{a}}$ & .794 & .778 & 2.08650 \\
\hline \multicolumn{2}{|l|}{ Sumber: SPSS (2019) } \\
\hline
\end{tabular}

Dari hasil pengujian pada tabel 6 maka dapat diketahui pada kolom Adjusted $R$ Square menunjukkan angka sebesar 0,778 . Hasil ini menunjukkan bahwa $0,778(77,8 \%)$ dari setiap perubahan yang terdapat pada kemungkinan suatu perusahaan akan mengalami financial distress dapat dijelaskan oleh variabel-variabel independen yang ada. Sedangkan $22,2 \%$ sisanya dijelaskan oleh faktor-faktor lain yang tidak diteliti dalam penelitian ini. 
UJI F (UJI SIMULTAN)

Tabel 7. ANOVA

\begin{tabular}{|l|l|r|r|r|r|c|}
\hline \multicolumn{2}{|l|}{ Model } & Sum of Squares & df & Mean Square & F & Sig. \\
\hline \multirow{3}{*}{1} & Regression & 1539.928 & 7 & 219.990 & 50.532 & $.000^{\mathrm{a}}$ \\
\cline { 2 - 7 } & Residual & 400.521 & 92 & 4.353 & & \\
\cline { 2 - 7 } & Total & 1940.449 & 99 & & & \\
\hline
\end{tabular} $\begin{aligned} & \text { a. Predictors: (Constant), LEV, INDCOM, PROFIT, LIKUID, KEPMEN, KEPINST, DIRSIZE } \\
& \text { b. Dependent Variable: Z-SCORE } \\
& \text { Sumber: SPSS (2019) }\end{aligned}$

Berdasarakan hasil pengujian pada tabel 7 dapat diketahui bahwa nilai signifikansi sebesar 0,000 dimana nilai tersebut lebih kecil dari 0,05 maka dapat disimpulkan bahwa model regresi dapat digunakan dalam memprediksi financial distress atau dapat dikatakan bahwa kepemilikan institusional,

Berdasarakan hasil pengujian pada tabel 7 dapat diketahui bahwa nilai signifikansi sebesar 0,000 dimana nilai tersebut lebih kecil dari 0,05 maka dapat disimpulkan bahwa model regresi dapat digunakan dalam memprediksi financial distress atau dapat dikatakan bahwa kepemilikan institusional, kepemilikan manajerial, ukuran dewan direksi, proporsi komisaris independen, likuiditas, profitabilitas dan leverage secara bersama-sama mempengaruhi terhadap financial distress (diproksikan dengan nilai Z-Score).

\section{UJI $t$ (UJI PARSIAL)}

Tabel 8. Koefisien Regresi

\begin{tabular}{|c|c|c|c|c|c|c|}
\hline \multirow{2}{*}{\multicolumn{2}{|c|}{ Model }} & \multicolumn{2}{|c|}{$\begin{array}{l}\text { Unstandardized } \\
\text { Coefficients }\end{array}$} & \multirow{2}{*}{$\begin{array}{c}\begin{array}{c}\text { Standardized } \\
\text { Coefficients }\end{array} \\
\text { Beta }\end{array}$} & \multirow[b]{2}{*}{$\mathrm{t}$} & \multirow[b]{2}{*}{ Sig. } \\
\hline & & B & Std. Error & & & \\
\hline \multirow[t]{8}{*}{1} & (Constant) & -1.252 & 2.044 & & -.613 & .542 \\
\hline & KEPINST & .035 & .013 & .180 & 2.724 & .008 \\
\hline & KEPMEN & .082 & .022 & .229 & 3.676 & .000 \\
\hline & DIRSIZE & .107 & .154 & .048 & .697 & .487 \\
\hline & INDCOM & 2.635 & 2.980 & .052 & .884 & .379 \\
\hline & LIKUID & 1.673 & .130 & .694 & 12.885 & .000 \\
\hline & PROFIT & 11.988 & 3.423 & .187 & 3.502 & .001 \\
\hline & LEV & -5.789 & 2.061 & -.214 & -2.809 & .006 \\
\hline
\end{tabular}

Sumber: SPSS 2019

\section{PEMBAHASAN}

Berdasarkan hasil dari pengujian tersebut diketahui arah hubungan secara parsial antara kepemilikan institusional, kepemilikan manajerial, ukuran dewan direksi, proporsi komisaris independen, likuiditas, profitabilitas dan leverage terhadap variabel dependen financial distress berupa nilai Z-Score yang dapat dijelaskan sebagai berikut:

\section{Pengaruh Kepemilikan Institusional terhadap Financial Distress}

Berdasarkan pada tabel 9 variabel kepemilikan institusional yang diukur dengan melihat presentase kepemilikan saham oleh institusi yang ada pada perusahaan maka dapat disimpulkan dengan nilai koefisien regresi 0,035 dimana arah koefisien menunjukkan arah positif antar variabel Kepemilikan Institusional dan Z-Score dengan nilai sig 0,008 < alpha 0,05. Sehingga dapat disimpulkan bahwa kepemilikan institusional berpengaruh signifikan secara positif terhadap financial distresss berupa nilai Z-Score.

Hasil tersebut sejalan dengan penelitian yang dilakukan oleh Cinantya dan Merkusiwati (2015) dan Deviacita (2012) yang menyatakan bahwa kepemilikan saham institusional berpengaruh terhadap kondisi financial distress. Dimana tingginya tingkat kepemilikan institusional berbanding lurus dengan kondisi kesehatan perusahaan itu sendiri, sehingga mampu menekan kemungkinan perusahaan terkena kondisi financial distress. 
Jurnal Akuntansi \& Perpajakan

Vol. 5 (2) 2019: 115-126

\section{Pengaruh Kepemilikan Manajerial terhadap Financial Distress}

Berdasarkan pada tabel 9 variabel kepemilikan manajerial yang diukur dengan melihat presentase kepemilikan saham oleh manajemen yang ada pada perusahaan maka dapat disimpulkan dengan nilai koefisien regresi 0,082 dimana arah koefisien menunjukkan arah positif antar variabel Kepemilikan Manajerial dan Z-Score dengan nilai sig 0,000 < alpha 0,05. Sehingga dapat disimpulkan bahwa kepemilikan manajerial berpengaruh signifikansecara positif terhadap financial distresss berupa nilai ZScore.

Hasil tersebut sejalan dengan penelitian Fathonah (2016) yang menyatakan bahwa kepemilikan manajerial berpengaruh dalam memprediksi kondisi financial distress. Hal ini dapat dijelaskan bahwa semakin tinggi tingkat kepemilikan manajerial suatu perusahaan maka kemungkinan perusahaan mengalami financial distress akan semakin kecil. Dengan adanya kepemilikan manajerial, perusahaan dapat mengurangi adanya agency problem yang timbul, dimana semakin tinggi proporsi kepemilikan saham oleh manajer maka akan semakin baik kinerja perusahaan.

\section{Pengaruh Ukuran Dewan Direksi terhadap Financial Distress}

Berdasarkan pada tabel 11 variabel ukuran dewan direksi yang diukur dengan menghitung jumlah keseluruhan dewan direksi yang ada pada perusahaan maka dapat disimpulkan dengan nilai koefisien regresi 0,107 dimana arah koefisien menunjukkan arah positif antar variabel Ukuran Dewan Direksi dan ZScore dengan nilai sig 0,487> alpha 0,05. Sehingga dapat disimpulkan bahwa ukuran dewan direksi tidak berpengaruh signifikan secara positif terhadap financial distresss berupa nilai Z-Score.

Hasil penelitian ini sesuai dengan penelitian Rangga (2017) dan Cinantya dan Merkusiwati (2015) yang menyatakan tidak adanya hubungan ukuran dewan direksi terhadap financial distress. Hal itu dikarenakan berapapun banyaknya dewan direksi yang dimiliki suatu perusahaan tidak akan mampu meminimalisir kemungkinan perusahaan dalam mengatasi kondisi financial distress jika perusahaan tersebut tidak mampu membayar kewajibannya yang dapat menimbulkan financial distress.

\section{Pengaruh Proporsi Komisaris Independen terhadap Financial Distress}

Berdasarkan pada tabel 11 variabel proporsi komisaris independen yang diukur dengan menghitung jumlah komisaris independen dibagi jumlah keseluruhan dewan komisaris yang ada pada perusahaan maka dapat disimpulkan dengan nilai koefisien regresi 2,635 dimana arah koefisien menunjukkan arah positif antar variabel Proporsi Komisaris Independen dan Z-Score dengan nilai sig 0,379> alpha 0,05. Sehingga dapat disimpulkan bahwa proporsi komisaris independen tidak berpengaruh signifikan secara positif terhadap financial distresss berupa nilai Z-Score.

Hasil penelitian ini sejalan dengan penelitian oleh Rangga (2017) dan Cinantya dan Merkusiwati (2015) yang menyatakan bahwa proporsi komisaris independen tidak memiliki pengaruh pada kesulitan keuangan atau financial distress. Hal tersebut dikarenakan sifat komisaris independen yang harus memiliki sikap objektif dan independensi dalam menjalankan tugasnya pada suatu perusahaan. Namun terkadang adanya bias dalam pelaksanaan independensinya yang dapat disebabkan oleh kecenderungan peran dewan direksi yang terlalu kuat sehingga mampu memperlemah sikap kompeten dan integritas komisaris independen dalam melaksanakan fungsinya.

\section{Pengaruh Likuiditas terhadap Financial Distress}

Berdasarkan pada tabel 11 variabel likuiditas yang diukur menggunakan current ratio dengan menghitung aktiva lancar dibagi hutang lancar yang ada pada laporan keuangan maka dapat disimpulkan dengan nilai koefisien regresi 1,673 dimana arah koefisien menunjukkan arah positif antar variabel Likuiditas dan Z-Score dengan nilai sig 0,000 < alpha 0,05. Sehingga dapat disimpulkan bahwa likuiditas berpengaruh signifikan secara positif terhadap financial distresss berupa nilai Z-Score.

Hasil penelitian ini sejalan dengan penelitian Cinantya dan Merkusiwati (2015) yang menyatakan bahwa rasio likuiditas berpengaruh dalam memprediksi kondisi financial distress. Hal tersebut dapat dikarenakan oleh rasio likuiditas perusahaan yang semakin besar memungkinkan perusahaan dalam membayarkan utang-utangnya, serta adanya cadangan berupa laba ditahan yang digunakan dalam membayar utang perusahaan yang akan jatuh tempo untuk mengatasi kemungkinan terjadinya kondisi financial distress. 


\section{Pengaruh Profitabilitas terhadap Financial Distress}

Berdasarkan pada tabel 11 variabel profitabilitas yang diukur menggunakan return on asset (ROA) dengan menghitung laba bersih dibagi total aset yang ada pada laporan keuangan maka dapat disimpulkan dengan nilai koefisien regresi 11,988 dimana arah koefisien menunjukkan arah positif antar variabel Profitabilitas dan Z-Score dengan nilai sig 0,001< alpha 0,05. Sehingga dapat disimpulkan bahwa profitabilitas berpengaruh signifikan secara positif terhadap financial distresss berupa nilai Z-Score.

Hal tersebut sesuai dengan penelitian yang dilakukan oleh Nora (2016) dan Rangga (2017) yang menyatakan bahwa profitabilitas dapat menekankan kondisi financial distress. Hal ini dikarenakan oleh suatu kondisi dimana perusahaan mampu menggunakan ekuitas dengan sebaik mungkin sehingga perusahaan mampu menghasilkan laba yang maksimal. Selain itu kinerja manajerial pada suatu perusahaan dapat dikatakan baik apabila tingkat profitabilitas yang dihasilkan tinggi selama periode tertentu.

\section{Pengaruh Leverage terhadap Financial Distress}

Berdasarkan pada tabel 11 variabel leverage yang diukur dengan menghitung total utang dibagi total aktiva yang ada pada laporan keuangan maka dapat disimpulkan dengan nilai koefisien regresi -5,789 dimana arah koefisien menunjukkan arah negatif antar variabel Leverage dan Z-Score dengan nilai sig $0,006<$ alpha 0,05. Sehingga dapat disimpulkan bahwa leverage berpengaruh signifikan secara negatif terhadap financial distresss berupa nilai Z-Score.

Hasil penelitian ini sejalan dengan penelitian Rangga (2017) dan Hanifah (2013) yang menyatakan bahwa leverage berpengaruh terhadap kondisi financial distress. Hal ini dikarenakan semakin besar jumlah leverage maka semakin besar kemungkinan perusahaan terkena financial distress. Hal itu dikarenakan tingkat hutang yang dimiliki perusahaan tinggi maka akan berakibat pada kemampuan perusahaan melunasi hutang beserta bunganya. Sehingga apabila dilihat dalam jangka panjang maka mampu mempersulit kondisi keuangan perusahaan yang bisa memicu terjadinya kondisi financial distress

\section{KESIMPULAN}

Dari hasil penelitian dan pembahasan yang dilakukan dengan menggunakan regresi linear berganda maka penelitian ini dapat disimpulkan sebagai berikut: secara simultan atau bersama-sama hubungan antar variabel independen yang dalam penelitian ini berupa kepemilikan institusional, kepemilikan manajerial, ukuran dewan direksi, proporsi komisaris independen, likuiditas, profitabilitas dan leverage berpengaruh secara signifikan terhadap variabel dependen financial distress. Secara parsial atau individu terdapat 4 variabel independen berupa kepemilikan institusional, kepemilikan manajerial, likuiditas dan profitabilitas yang berpengaruh signifikan positif terhadap financial distress dan 1 variabel yaitu leverage berpengaruh signifikan negatif terhadap financial distress. Sedangkan untuk 2 variabel independen berupa ukuran dewan direksi dan proporsi komisaris independen tidak berpengaruh terhadap kondisi perusahaan terkena financial distress.

Dari hasil penelitian dan pengambilan kesimpulan, maka berikut ini merupakan beberapa saran yang dapat diberikan sebagai bahan pertimbangan beberapa pihak untuk penelitian selanjutnya, antara lain sebagai berikut: Untuk penelitian selanjutnya, berdasarkan hasil analisis penelitian menunjukkan kemampuan dalam menjelaskan antara variabel independen terhadap variabel dependen dalam hal ini adalah financial distress hanya sebesar $77,8 \%$, sedangkan $22,2 \%$ dijelaskan oleh variabel lain yang tidak diteliti dalam penelitian ini. Dengan demikian untuk penelitian selanjutnya diharapkan mampu menggunakan indikatorindikator lain yang ada pada corporate governance dan financial indicators untuk memprediksi adanya kemungkinan financial distress pada suatu perusahaan seperti jumlah frekuensi pelaksanaan rapat umum pemegang saham (RUPS) yang dilaksanakan oleh perusahaan. Selain itu, untuk penelitian selanjutnya dalam penelitian mengenai financial distress dapat menggunakan alat analisis selain model Altman Z-Score seperti model Grover, Ohlson, Zavgren, Zmijewski dan lain-lain. Dan untuk periode penelitian yang digunakan bisa lebih panjang atau menambah rentang waktu sehingga dapat diperoleh hasil penelitian yang lebih akurat dan lebih baik. 


\section{DAFTAR PUSTAKA}

Altman, I. Edward dan Edith Hotchkiss. (2006). Corporate Financial Distress and Bankruptcy : Predict and Avoid Bankruptcy, Analyze and Invest in Distressed Debt .Third Edition. John Wiley \& Sons, Inc., Hoboken, New Jersey.

Aprianto, Devien. (2013). Analisis Pengaruh Corporate Governance Terhadap Kinerja Perusahaan dan Risiko Perusahaan (Studi Pada Perusahaan Non-Keuangan yang Terdaftar di Bursa Efek Indonesia dan Mengikuti Pemeringkatan Corporate Governance Perception Index (CGPI) Periode 20072011).Skripsi. Semarang : Fakultas Ekonomika dan Bisnis Universitas Diponegoro.

Ananto,R. P, Rasyidah, dan Desi. (2017). Pengaruh Good Corporate Governance (GCG), Leverage, Profitabilitas dan Ukuran Perusahaan Terhadap Financial Distress Pada Perusahaan Barang Konsumsi Yang Terdafat Di Bursa Efek Indonesia". Jurnal Ekonomi \& Bisnis Dharma Andalas, Volume 19, N0. 1

Anthony, R. N., dan V. Govindarajan. (2005). Management Control Sysytem (Sistem Pengendalian Manajemen). Edisi 11. Salemba Empat, Jakarta.

Bodroastuti, Tri. (2009). Pengaruh Struktur Corporate Governance terhadap Financial Distress. Skripsi. Sekolah Tinggi Ilmu Ekonomi Widya Manggala. Juli, 2009.

Bukhori, Iqbal. (2012). Pengaruh Good Corporate Goverance dan Ukuran Perusahaan Terhadap Kinerja Perusahaan (Studi Empiris pada Perusahaan yang Terdaftar di BEI 2010. Skripsi. Semarang : Fakultas Ekonomika dan Bisnis Universitas Diponegoro.

Cahyani, Diah Mentari dan Ni Nyoman A. Diantini. (2016). “Peranan Good Corporate Governance Dalam Memprediksi Financial Distress". Jurnal Manajemen, Strategi Bisnis dan Kewirausahaan, Vol. 10, No. 2

Cinantya, I Gusti A. Ayu. P dan Ni Kt. Lely A. Merkusiwati. (2015). Pengaruh Corporate Governance, Financial Indicators, dan Ukuran Perusahaan Pada Financial Distress.E-Jurnal Akuntansi. Universitas Udayana 10.3 (2015), Hal 897-915, ISSN : 2302-8556

Deviacita, Widya Arieany. (2012). Analisis Pengaruh Mekanisme Corporate Governance Terhadap Financial Distress. Skripsi. Semarang: Fakultas Ekonomika dan Bisnis Universitas Diponegoro.

Fathonah, Andina Nur. (2016). Pengaruh Penerapan Good Corporate Governance Terhadap Financial Distress. Jurnal Ilmiah Akuntansi, Vol. 2, No. 2, Hal : 133-150

Febrianto, Andra. (2010). Pengaruh Rasio Likuiditas, Rasio Profitabilitas, Rasio Leverage dan Rasio Aktivitas Terhadap Kebijakan Dividen Pada Perusahaan Kelompok Indeks LQ-45 Periode 2003-2008 di Bursa Efek Indonesia. Skripsi. Bandung : Fakultas Bisnis dan Manajemen Universitas Widyatama.

Forum for Corporate Governance in Indonesia. (2001). Corporate Governance: Tata Kelola Perusahaan.Edisi kedua. Jakarta: Prentice Hall.

Gurria, Angel. (2015). G20/OECD Principles of Corporate Governance (OECD Report to G20 Finance Ministers and Central Bank Governors). September 2015.

Hanifah, Oktita Earning dan Purwanti, Agus. (2013). Pengaruh Struktur Corporate Governance dan Financial Indicator terhadap Kondisi Financial Distress Perusahaan Manufaktur periode 2009-2011. Jurnal of accounting, Vol. 2, No. 2, Hal 1, ISSN (online) :2337-3806

Harahap, Lili Wardani. (2017). Pengaruh Mekanisme Corporate Governance dan Firm Size Terhadap Kondisi Financial Distress Pada Perusahaan Property and Real Estate yang Terdaftar Di Bei Tahun 2010-2014. Jurnal Riset Akuntansi \& Bisnis, Vol. 17, No. 2, ISSN : 1693-7597

Komite Nasional Kebijakan Governance. (2006). Pedoman Umum Good Corporate Governance Indonesia. Jakarta, 2006.

Maniik, Wida F. (2012). Good Corporate Governance (GCG. https://manikwida. blogspot.com /2012/11/good-corporate-governance-gcg_7704.html (diakses tanggal 29 September 2018) 
Nirmalasari, Laksita. (2018). Analisis Financial Distress Pada Perusahaan Sektor Property, Real Estate dan Kontruksi Bangunan yang Terdaftar di Bursa Efek Indonesia. Skripsi. Yogyakarta : Fakultas Ekonomi Universitas Negeri Yogyakarta.

Noorizkie, Giska. (2013). Pengaruh Mekanisme Corporate Governance Terhadap Kinerja Keuangan Perusahaan (Studi Empiris pada Perusahaan Manufaktur yang Terdaftar di Bursa Efek Indonesia. Skripsi. Semarang : Fakultas Ekonomika dan Bisnis Universitas Diponegoro.

Nora, Alfi Rista. (2016). Pengaruh Financial Indicators, Ukuran Perusahaan dan Kepemilikan Institusional Terhadap Financial Distress (Studi Empiris pada Perusahaan Property dan Real Estate yang Terdaftar Di BEI). Artikel Ilmiah. Surabaya : Sekolah Tinggi Ekonomi Perbanas.

Pramuditya, Andhika Yudha. (2014). Analisis Pengaruh Mekanisme Corporate Governance Terhadap Kemungkinan Perusahaan Mengalami Kondisi Financial Distress (Studi Empiris Perusahaan Manufaktur Yang Terdaftar di Bursa Efek Indonesia Tahun 2010-2012). Skripsi. Semarang : Fakultas Ekonomika dan Bisnis Universitas Diponegoro.

Santoso, Githa A. Pradewi, Yulianeu, Aziz Fathoni. (2018). Analysis Of Effect Of Good Corporate Governance, Financial Performance And Firm Size On Financial Distress In Property And Real Estate Company Listed BEI 2012-2016. Jurnal of Management, Vol. 4, No. 4. ISSN : 2502-7689

Suhaeni, Martini. (2015). Pengaruh Likuiditas, Profitabilitas, Leverage, Dan Pertumbuhan Terhadap Prediksi Kondisi Financial Distress (Suatu Studi pada Perusahaan Sektor Pertambangan yang Terdaftar di Bursa Efek Indonesia). Skripsi. Bandung : Fakultas Ekonomi Universitas Pasundan.

Triwahyuningtias, Meilinda. (2012). Analisis Pengaruh Struktur kepemilikan, Ukuran Dewan, Komisaris Independen, Likuiditas dan Leverage Terhadap Terjadinya Kondisi Financial Distress (Studi Pada Perusahaan Manufaktur yang Terdaftar di Bursa Efek Indonesia Periode Tahun 2008-2010). Skripsi. Semarang Fakultas Ekonomika dan Bisnis Universitas Diponegoro.

Winata, Raden. (2013). “Pengertian, Jenis \& Rumus Analisis Rasio Likuiditas. https://radenwinata.com/ pengertian-jenis-rumus-analisis-rasio-likuiditas.html (diakses tanggal 1 Oktober 2018)

http://www.bpkp.go.id/dan/konten/299/Good-Corporate.bpkp

https://www.idx.co,id

https://www.statistikian.com

https://www.sahamok.com. 